\title{
First versus second stage caesarean section: a comparison of maternal and neonatal outcomes
}

\author{
Sushma Sinha, Surya Malik*, Mala Dixit
}

Department of Obstetrics and Gynecology, ABGH Hospital, Government of NCT of Delhi, Moti Nagar, New Delhi, India

Received: 25 May 2017

Accepted: 20 June 2017

*Correspondence:

Dr. Surya Malik,

E-mail: surya85.sm@gmail.com

Copyright: () the author(s), publisher and licensee Medip Academy. This is an open-access article distributed under the terms of the Creative Commons Attribution Non-Commercial License, which permits unrestricted non-commercial use, distribution, and reproduction in any medium, provided the original work is properly cited.

\section{ABSTRACT}

Background: A retrospective study was done to compare the maternal and neonatal complications of caesarean delivery performed in the second stage compared with the first stage of labor.

Methods: This is a one year retrospective study done in a 100-bedded hospital, govt of NCT OF Delhi, New Delhi from $1^{\text {st }}$ November 2015 to $31^{\text {st }}$ October 2016. Total number of deliveries in this one year duration were 1785, including both normal and caesarean deliveries. Total number of patients who underwent caesarean delivery in the first stage of labor were 159 , and in 2 nd stage of labor were 15 during this time period. These were designated into two groups, group 1 and group 2. These two groups were then compared in terms of maternal demographics, labor characteristics, maternal outcomes and neonatal outcomes. Numerical variables were compared between groups by calculating P-value for each variable. P-value $<0.05$ was considered statistically significant.

Results: Caesarean deliveries performed in the second stage were associated with increased maternal morbidity in terms of blood loss, unintended extensions, blood transfusions, prolonged hospital stay, febrile morbidity. Similarly, Neonatal morbidity was much higher in the patient who underwent LSCS in $2^{\text {nd }}$ stage of labor compared to 1 st stage. There was increase in neonatal complications, for e. g. -5 minute Apgar $<7$, NICU admissions $>24$ hrs, neonatal septicaemia, (P-value <0.05).

Conclusions: In conclusion, present study suggests that women undergoing caesarean section in the second stage of labor have increased maternal and fetal morbidity. Therefore, selection of birthing method should be made very carefully and meticulously to decrease maternal and neonatal morbidity.

Keywords: Caesarean delivery, Neonatal septicaemia, Fetal pillow

\section{INTRODUCTION}

Caesarean section (CS) is the most commonly performed major abdominal operation in women in both industrialised and low-income countries. ${ }^{1-3}$ Caesarean section rate has been rising continuously and the trend is likely to continue in future.

This increase has been a global phenomenon. The timing and rate of increase are different from one country to another. In 1970 the caesarean section rate in United
Kingdom was reported to be $4.8 \%$. The audit commission in 1997 found this rate increased to $11-18 \% .^{4}$ Arate of 45\% was reported in Puerto Rico between 1996 and $2002 .{ }^{5}$

In Medical colleges and teaching hospitals in India the overall rate of caesarean deliveries is $24.4 \% .^{6}$ In a population based cross sectional study, the public, charitable and private sector hospitals had caesarean section rates of $20 \%, 38 \% 47 \%$ respectively. ${ }^{7}$ Recent data suggest that caesarean delivery in labor, is associated 
with increased maternal morbidity compared with caesarean delivery with no labor. ${ }^{8}$

During the last three decades, it appears that assisted vaginal delivery such as forceps and vacuum extraction, traditionally used for arrest of descent, have been replaced by c/s during the second stage of labor. ${ }^{9,10}$ One fourth of the primary caesarean sections are reported to be performed in the second stage of the labor and are more complicated compared to the ones performed in the first stage. ${ }^{11,12}$

Caesarean section during the second stage of labor with an engaged head in generally thought to carry higher maternal morbidity, usually resulting from tearing of the lower uterine segment, extension of the uterine incision and incision of the urinary bladder. Furthermore, the delay in the decision to perform an emergency caesarean section for reasons of fetal distress puts the fetus at increased risk of developing hypoxia, thus risking brain damage that leads to varying forms of disabiliy in its life. ${ }^{13}$

\section{METHODS}

This is a one year retrospective study done in a 100 bedded hospital, Govt. of NCT of Delhi, New Delhi from $1^{\text {st }}$ November 2015 to $31^{\text {st }}$ October 2016. Total number of deliveries during this period were 1785 , including both normal and caesarean deliveries.

First stage of labor was defined as the period of time when there were regular contractions associated with cervical change (dilatation $>4 \mathrm{cms}$ ). Second stage of labor was defined as the period of time from full cervical dilatation $(10 \mathrm{cms})$ to delivery.

\section{Inclusion criteria}

- $\quad$ Singleton pregnancies > 37 weeks of POG.

- Fetus with vertex presentation

- No maternal comorbidities or associated obstetric complications such as preeclampsia, diabetes mellitus.

Total number of patients who underwent caesarean delivery in the first stage of laborwere 159, and in second stage of labor were 15 during this time period. These were designated as

- Group 1- Caesarean delivery in the first stage of labor (n-159)

- Group 2-Caesarean delivery in the second stage of labor (n-15)

These two groups were then compared in terms of maternal demographics, labor characteristics, maternal outcomes and neonatal outcomes. Numerical variables were compared between groups by calculating P-Value for each variable. $\mathrm{P}$ value $<0.05$ was considered statistically significant.

\section{RESULTS}

During this one year period, total 1785 deliveries took place in our hospital, including both normal and caesarean deliveries. Caesarean section rate in our hospital was $22.63 \%$. Out of these 404caesarean deliveries, 159 women who underwent caesarean delivery during the first stage of labor and 15 women who underwent caesarean delivery during the second stage of labor were included.

Table 1: Maternal demographics and Labor characterstics.

\begin{tabular}{|llll|}
\hline Variables & $\begin{array}{l}\text { Group 1 } \\
(\mathrm{n}-159)\end{array}$ & $\begin{array}{l}\text { Group 2 } \\
(\mathrm{n}-15)\end{array}$ & $\begin{array}{l}\text { P- } \\
\text { value }\end{array}$ \\
\hline Mean maternal age & $24.75 \pm 3.97$ & $24.40 \pm 3.70$ & 0.740 \\
\hline $\begin{array}{l}\text { Mean period of } \\
\text { gestation }\end{array}$ & $39.24 \pm 1.38$ & $39.25 \pm 1.12$ & 0.978 \\
\hline $\begin{array}{l}\text { \% of nulliparity } \\
\text { Mean dilatation of } \\
\text { cervix at delivery }\end{array}$ & $83 \%$ & $73.3 \%$ & 0.312 \\
\hline $\begin{array}{l}\text { No of patients } \\
\text { induced/augmented }\end{array}$ & 128 & 10 & $<0.001$ \\
\hline $\begin{array}{l}\text { Duration of labor } \\
\text { (hrs) }\end{array}$ & $9.71 \pm 2.79$ & $11.13 \pm 1.88$ & $<0.015$ \\
\hline $\begin{array}{l}\text { Operative duration } \\
\text { (min) }\end{array}$ & $34.23 \pm 5.84$ & $43.33 \pm 6.46$ & $<0.001$ \\
\hline $\begin{array}{l}\text { Length of Hospital } \\
\text { Stay (days) }\end{array}$ & $8.11 \pm 1.83$ & $11.87 \pm 5.25$ & $<0.001$ \\
\hline
\end{tabular}

Maternal demographics and labor characteristics are well depicted in Table 1. There was no significant difference noted for mean maternal age, mean period of gestation, $\%$ of nullipara between group 1 and 2 patients. The number of women who were induced/augmented in group 1 were 128 out of 159 and 13 out of 15 giving a $p$ value of $<0.001$.

Mean dilatation in group 1 was $5 \mathrm{cms}$ while in the group 2 was $10 \mathrm{cms}$ which is significant giving a period of $<0.001$. Operative duration and Length of hospitalisation were significantly greater in group $2(43.33 \pm 6.46 \mathrm{~min}$, $11.87 \pm 5.25$ days $)$, than group $1 \quad(34.23 \pm 5.84 \mathrm{~min}$, $8.11 \pm 1.83$ days), (p- value $<0.001)$.

Maternal morbidity in both groups wascalculated and comparative analysis was done in terms of $\mathrm{p}$-value (Table 2).

In Group 1 only $3 \%$ patient underwent blood transfusion where as in group 2 blood transfusions was done in $26.7 \%$ patients, thus giving a p-value of 0.004 , which is significant.

Bladder high up and hematuria like complications were more commonly encountered in group 2 than group 1 (p- 
value $<0.001)$. Unintended extensions were significantly greater in group 2 than group 1 ( $\mathrm{p}$-value $<0.001$ ). Wound dehiscence and febrile morbidity were encountered more in group 2 than group 1 ( $\mathrm{p}$-value $<0.001$ ).

Table 2: Maternal outcomes.

\begin{tabular}{|c|c|c|c|c|c|}
\hline \multirow{3}{*}{ Maternal complications } & \multicolumn{4}{|c|}{ Group } & \multirow{3}{*}{ P value } \\
\hline & \multicolumn{2}{|c|}{ Group $1(n=159)$} & \multicolumn{2}{|c|}{ Group $2(n=15)$} & \\
\hline & Frequency & $\%$ & Frequency & $\%$ & \\
\hline Atonic PPH & 8 & 5.0 & 3 & 20.0 & 0.056 \\
\hline Uterine artery ligation & 1 & 0.6 & 1 & 6.7 & 0.165 \\
\hline Blood transfusions & 5 & 3.1 & 4 & 26.7 & 0.004 \\
\hline Bladder high up & 2 & 1.3 & 6 & 40 & $<0.001$ \\
\hline Hematuria & 3 & 1.9 & 5 & 33.3 & $<0.001$ \\
\hline Unintended extensions & 3 & 1.9 & 6 & 40 & $<0.001$ \\
\hline Wound dehiscence & 6 & 3.8 & 5 & 33.3 & $<0.001$ \\
\hline Febrile morbidity & 6 & 3.8 & 5 & 33.3 & $<0.001$ \\
\hline
\end{tabular}

Table 3: Neonatal outcomes.

\begin{tabular}{|c|c|c|c|}
\hline Outcomes & $\begin{array}{l}\text { Group } 1 \\
(\mathbf{n}=159)\end{array}$ & $\begin{array}{l}\text { Group } 2 \\
(\mathrm{n}=15)\end{array}$ & $\begin{array}{l}\mathbf{P} \\
\text { Value }\end{array}$ \\
\hline Mean birth weight & $2.90 \pm 0.36$ & $2.92 \pm 0.39$ & 0.778 \\
\hline $\begin{array}{l}\text { Apgar Score at } 5 \\
\text { min }\end{array}$ & $8.28 \pm 1.06$ & $7.00 \pm 2.17$ & 0.039 \\
\hline $\begin{array}{l}\text { Apgar Score }<7 \text { at } \\
5 \mathrm{~min}\end{array}$ & $12(7.5 \%)$ & $5(33.3 \%)$ & 0.001 \\
\hline $\begin{array}{l}\text { Neonatal } \\
\text { septicaemia }\end{array}$ & $7(4.4 \%)$ & $3(20 \%)$ & 0.043 \\
\hline $\begin{array}{l}\text { Intubation not for } \\
\text { meconium }\end{array}$ & $1(0.6 \%)$ & $4(26.7 \%)$ & 0.0002 \\
\hline NICU stay $>24 \mathrm{hrs}$ & $13(8.2 \%)$ & $7(46.7 \%)$ & $<0.001$ \\
\hline Neonatal Death & $1(0.6 \%)$ & $1(6.7 \%)$ & 0.165 \\
\hline Neonatal seizure & $0(0.0 \%)$ & $1(6.7 \%)$ & 0.086 \\
\hline
\end{tabular}

Neonatal outcomes were defined in terms of NICU admission >24 hrs, 5 min APGAR score less than 7, Neonatal septicaemia, Neonatal deaths etc. 5 min APGAR score less than 7 was commoner in group 2 patients than group 1. Similarly, chances of neonatal septicaemia, NICU stay $>24 \mathrm{hrs}$, Intubation other than meconium were more prevalent in the patients undergoing c-section in the second stage of labor ( $p$-value $<0.05)$. There was one neonatal death in the group 1 $(0.6 \%)$ and one death in the group $2(6.7 \%)$. Both these babies had APGAR <3 at $1 \mathrm{~min}$ and $5 \mathrm{~min}$ respectively and were admitted in NICU >24 hrs. They were on ventilator support and finally died after 2 days (Table 3 ). Hence neonatal morbidity was definitely greater in group 2 patients than group 1 .

\section{DISCUSSION}

The present study clearly demonstrated that women who underwent caesarean delivery in the second stage of laborhad significantly higher maternal and neonatal morbidity.
In the present study regarding the maternal demographics and laborcharacterstics, number of women who underwent induction and augmentation were definitely larger in number in group 2 than group 1 ( $p$-value $<0.05$ ). Similar findings were reported by Asicioglu et al and Das S. ${ }^{14,15}$ Maternal morbidity as reported by Allen VM, Asicioglu et al, Sucak A, Rabiu KA is greater in group 2 than group $1 .{ }^{14,16-18}$

Caesarean delivery performed in the second stage of labor increases the incidence of fetal injury, septicaemia, NICU admissions and fetal deaths due to fetal head impaction into the maternal pelvis, and prolonged second stage labor.

Thus, this leads to increased incidence of birth asphyxia, and decrease in 5 minute Apgar scores. This finding was similar to the studies by Allen VM, Sucak A, Rabiu KA and Radha P. ${ }^{16-19}$

A recent study by Das $S$ demonstrated a statistically significant increase in admission to NICU, septicaemia, low 5 min Apgar $(<3)$ and neonatal trauma. ${ }^{15}$

\section{CONCLUSION}

In conclusion, present study suggests that women undergoing caesarean section in the second stage of labor have increased maternal and fetal morbidity and requires special care and especially the patient who undergo caesarean section during the second stage of labor. Therefore selection of birthing method should be made carefully and meticulously to decrease maternal and neonatal morbidity.

Funding: No funding sources

Conflict of interest: None declared

Ethical approval: The study was approved by the Institutional Ethics Committee 


\section{REFERENCES}

1. Dumont A, De Bernis L, Bouvier-olle MH, Bréart G, MOMA Study Group. Caesarean section rate for maternal indication in sub-Saharan Africa: a systematic review. Lancet. 2001;358(9290):1328-33.

2. Murray SF, Pradenas FS. Health sector reform and rise of caesarean with in Chile. Lancet. 1997;349(9044):64.

3. Pai M, Sundaram P, Radhakrishnan KK, Thomas K, Muliyil JP. A high rate of Caesarean sections in an affluent section of Chennai is it cause for concern? Natl Med J India. 1999;12(4):156-8.

4. Jolly J, Walker J, Bhadra K. Subsequent obstetric performance related to mode of delivery. Br J Obstet Gynecol. 1999;10.6 (3):277-32.

5. Varela FR, Vazquez RH, Menacker F, Ahmed Y, Grant AM, Jamieson DJ. Rates of caesarean delivery among Puerto Rican women. Puerto Rico and the U.S main land 1992-2002. MMWR Morb Mortal Wkly Rep. 2006 Jan 27;55(3):68-71.

6. Kambo I, Bedi N, Dhillon BS, Saxena NC. A critical appraisal of caesarean section rates at teaching hospitals in India. Int $\mathbf{J}$ Gynaecol Obstet. 2002;79(2):151-8.

7. Sreevidya S, Sathiyasekaran BW. High caesarean rates Madras (India): a population based cross sectional study. BJOG. 2003;110:106-111.

8. Allen VM, O' Connel, Basket TF. Maternal morbidity associated with caesarean delivery without labor compared with spontaneous onset of labor at term. Obstet Gynecol. 2003;102:477-82.

9. Gei AF. Prevention of the first caesarean delivery: the role of operative vaginal delivery. Semin Perinatol. 2012;36:365-73.

10. Bailey PE. The disappearing art of instrumental delivery ;time to reverse the trend. Int $\mathrm{J}$ Gynecol Obstet. 2005;91:89-96.

11. Gifford DS, Morton SC, Fiske M, Keesey J, Keeler E, Kahn KL. Lack of progress in labor as a reason for cesarean. Obstet Gynecol. 2000;95(4):589-95.
12. Seal SL, Kamilya G, Mukherji J, Bhattacharyya SK, De A, Hazra A. Outcome in second-versus first-stage cesarean delivery in a teaching institution in eastern India. Am J Perinatol. 2010;27(06):507-12.

13. Leung TY, Lao TT. Timing of caesarean section according to urgency. Best Prac Res Clin Obstet Gynecol. 2013;27:251-67.

14. Asicioglu O, Gungorduk K, Yildirim G, Asicioglu BB, Gungorduk OC, Ark C et al. Second- stage vs first stage caesarean delivery: Comparison of maternal and perinatal outcomes. J Obstet Gynecol. 2014;34(7):598-604.

15. Das S, Sarkar SK. Fetomaternal outcome in second versus First stage caesarean delivery in a tertiary rural medical college. IOSR J Dent Med Sci. 2014;13(12):28-30.

16. Allen VM, O' Connel CM, Baskett TF. Mternal and perinatal morbidity of caesarean delivery at full cervical dilatation compared with caesarean delivery in the first stage of labor. BJOG. 2005;112:986-90.

17. Sucak A, Celen S, Akbaba E, Soysal S, Moraloglu $\mathrm{O}$, Danisman N. Comparison of nulliparas undergoing caesarean section in first and second stage of labor: a prospective study in a tertiary teaching hospital. Obstet Gynecol Int. 2011;2011:986506.

18. Rabiu KA, Adewunmi AA, Akinola OI, Eti AE, Tayo AO. Comparison of maternal and neonatal outcomes following caesarean section in second versus first stage of labor in a tertiary hospital in Nigeria. Niger Postgrad Med J. 2011;18:165-71.

19. Radha P, Tagore S, Rahman MF, Tee J. Maternal and perinatal morbidity after caesarean delivery at full cervical dilatation. Singapore Med J. 2012;53:655-8.

Cite this article as: Sinha S, Malik S, Dixit M. First versus second stage caesarean section: a comparison of maternal and neonatal outcomes. Int J Reprod Contracept Obstet Gynecol 2017;6:3477-80. 